Volume 1, Issue 1, Serial 2: August 2012

\title{
DEVELOPMENT AND VALIDATION OF RP-HPLC METHOD FOR ESTIMATION OF VILDAGLIPTIN FROM TABLET DOSAGE FORM
}

\author{
Aparajita Malakar*, Bishwajit Bokshi, Dilruba Nasrin \\ Pharmacy Discipline, Life Science School, Khulna University, Khulna-9208, \\ Bangladesh.
}

\begin{abstract}
A new simple, specific, precise and accurate reversed-phase liquid chromatography method has been developed for the determination of Vildagliptin (VLG) in pharmaceutical dosage form. The separation was achieved on a Xterra® Waters $\mathrm{C}_{18}$ column $(150 \mathrm{~mm} \times 4.6 \mathrm{~mm}, 5 \mu \mathrm{m})$ using mobile phase consisting of a mixture of aqueous phase ( $1 \mathrm{ml}$ of $25 \%$ ammonium hydroxide was dissolved in $1000 \mathrm{ml}$ of water for chromatography, $\mathrm{pH}$ of the solution was adjusted to the value of 9.5 using a $50 \%$ solution of phosphoric acid ) and organic phase (methanol) in the ratio of $60: 40 \mathrm{v} / \mathrm{v}$ at a flow rate of $1.0 \mathrm{ml} / \mathrm{min}$. Detection was carried out at $210 \mathrm{~nm}$. The retention time of Vildagliptin was found to be $6.3 \mathrm{~min}$. The calibration curve was found linear between 5$200 \mu \mathrm{g} / \mathrm{ml}\left(\mathrm{r}^{2}=0.9997\right)$. Limit of detection and limit of quantitation were 1.47 and 4.90 $\mu \mathrm{g} / \mathrm{mL}$, respectively. The percentage recoveries of Vildagliptin were found to be in the range of $99.11-100.62 \%$. The method was validated in accordance with International Conference on Harmonization acceptance criteria for specificity, linearity, precision, accuracy, robustness and system suitability. The excipients did not interfere in the determination of VLG. The proposed method was successfully applied for the quantitative analysis of VLG in tablet dosage form, which will help to improve quality control.
\end{abstract}

Key Words: Vildagliptin, analytical method validation, HPLC

"Corresponding Author:

Aparajita Malakar

Pharmacy Discipline

Khulna University

Mobile No.: +8801739370508

E-mail Address: aparajitamalakar@gmail.com

\section{INTRODUCTION}

Vildagliptin (VDG), S-1-[N-(3-hydroxy-1adamantyl) glycyl] pyrrolidine-2carbonitrile (Fig.1) is an oral antihyperglycemic agent (anti-diabetic drug) 
Volume 1, Issue 1, Serial 2: August 2012

of the new dipeptidyl peptidase-4 (DPP4) inhibitor class of drugs. Vildagliptin inhibits the inactivation of GLP1 and GIP by DPP-4, allowing GLP-1 and GIP to potentiate the secretion of insulin in the beta cells and suppress glucagon release by the alpha cells of the islets of Langerhans in the pancreas. Vildagliptin has been shown to reduce hyperglycemia in type 2 diabetes mellitus ${ }^{1}$. Literature survey revealed that few analytical methods are used for estimation of Vildagliptin ${ }^{2}$, 3 . But there is no analytical method for the determination of Vildagliptin from its pharmaceutical dosage form. Due to lack of published liquid chromatographic methods for VDG, so the aim of the present work was to develop a reversed-phase liquid chromatographic (RP-LC) method that would be suitable for the determination of VDG from its pharmaceutical dosage form. The proposed method is simple, accurate, reproducible and suitable for routine determination of Vildagliptin from its pharmaceutical dosage form.

\section{MATERIAL AND METHODS \\ Chemicals and Reagents}

Pharmaceutical grade Vildagliptin, certified to contain $99.72 \%$ and Galvus tablets nominally containing $50 \mathrm{mg}$ Vildagliptin per tablet were kindly supplied from Novartis Europharm limited company (London, U.K.). HPLCgrade Methanol, ammonium hydroxide (25\%) and orthophosphric acid (85\%) were obtained from Merck, Darmstadt, Germany. HPLC grade water was obtained through milli $Q$ water purification system.

\section{Instruments}

The HPLC system consisted of a Schimadzu LC-20 AT Liquid Chromatograph (Japan) using a Xterra ${ }^{\circledR}$ Waters $\mathrm{C}_{18}$ column $(150 \mathrm{~mm} \times 4.6 \mathrm{~mm}$, $5 \mu \mathrm{m}) \quad$ (Ireland).The system was equipped with a UV-visible detector (SPD-20A, Japan) and an autosampler (SIL-20A, Schimadzu, Japan). An Elma S100 ultrasonic processor model KBK 4200 (Germany) was used for the degassing of the mobile phases. In addition, an electronic balance (Shimadzu AX200), a pH meter (Systronics model EQMK Vl), a 
Volume 1, Issue 1, Serial 2: August 2012

sonicator (Spectra Lab, model UCB 40) were used in this study.

\section{Chromatographic conditions}

Chromatographic separation was achieved on a Xterra $\AA$ Waters $\mathrm{C}_{18}$ column $(150 \mathrm{~mm} \times 4.6 \mathrm{~mm}, 5 \mu \mathrm{m})$ with UV detection at $210 \mathrm{~nm}$. Aqueous phase was prepared by dissolving $1 \mathrm{ml}$ of $25 \%$ ammonium hydroxide in $1000 \mathrm{ml}$ of water and $\mathrm{pH}$ of solution was then adjusted to 9.5 with using a $50 \%$ solution of phosphoric acid. HPLC-grade Methanol was used as organic phase. Mobile phase was prepared by mixing aqueous phase and organic phase in the ratio of $60: 40 \mathrm{v} / \mathrm{v}$. The mobile phase was degassed for $30 \mathrm{~min}$ and filtered through $0.2 \mu \mathrm{m}$ Nylon 6, 6 membrane filters before use. The mobile phase was pumped through the column at a flow rate of $1 \mathrm{~mL}$ min-1. Analyses were performed at $30^{\circ} \mathrm{C}$ and the injection volume was $25 \mu \mathrm{L}$.

\section{Preparation of Stock Solution}

About $100 \mathrm{mg}$ of Vildagliptin WS was weighed accurately into a $100 \mathrm{ml}$ volumetric flask and dissolved and diluted to volume with mobile phase to obtain a concentration of $1000 \mu \mathrm{g} / \mathrm{ml}$ and this solution was used as stock solution.

\section{Calibration curve for Vildagliptin}

Appropriate aliquots of stock solution was taken in different $50 \mathrm{ml}$ volumetric flasks and diluted up to the mark with mobile phase to obtain final concentrations of $5-200 \mu \mathrm{g} / \mathrm{ml}$. The solutions were injected into HPLC with $25 \mu \mathrm{l}$ inject volume and chromatograms were recorded. Calibration curve was constructed by plotting average peak areas versus concentrations and regression equation was computed for the drugs (Table 1 ).

\section{Analysis of Marketed Formulation}

Twenty tablets were weighed. An accurately weighed amount of the finely powdered Galvus tablets equivalent to $100 \mathrm{mg}$ of VDG was taken and transferred into a $100 \mathrm{ml}$ volumetric flask; $60 \mathrm{ml}$ of mobile phase was added and sonicated with occasional shaking for $10 \mathrm{~min}$. The solution was cooled to room temperature and diluted to volume with the mobile phase. The resultant solution was filtered through Whatman 1 
Volume 1, Issue 1, Serial 2: August 2012

filter paper. $5 \mathrm{ml}$ of this solution was diluted to $50 \mathrm{ml}$ with mobile phase. The final solution was filtered through $0.20 \mu \mathrm{m}$ PTFE membrane filter. $25 \mu \mathrm{l}$ volume of final sample solution was injected into HPLC and peak areas were measured under optimized chromatographic conditions.

\section{Procedure}

\section{Method Validation}

The method of analysis was validated as per the recommendations of $\mathrm{ICH}^{4}$ and $\mathrm{USP}^{5}$ for the parameters like accuracy, linearity, precision, detection limit, quantitation and robustness. The accuracy of the method was determined by calculating percentage recovery of Vildagliptin. For the drug, recovery study was carried out by applying the method to drug sample to which known amount of Vildagliptin corresponding to $80 \%$, $100 \%$ and $120 \%$ of label claim had been added (standard addition method). At each level of the amount six determinations were performed and the results obtained were compared. Intraday and interday precision study of Vildagliptin was carried out by estimating the corresponding responses
3 times on the same day and on 3 different days for the concentration of $100 \mu \mathrm{g} / \mathrm{ml}$ of Vildagliptin. The limit of detection (LOD) and limit of quantitation (LOQ) were calculated using following formulae: $L O D=3.3(S D) / S$ and $L O Q=$ $10 \quad(\mathrm{SD}) / \mathrm{S}$, where $\mathrm{SD}=$ standard deviation of response (peak area) and $S=$ average of the slope of the calibration curve. System suitability tests are an integral part of chromatographic method which is used to verify reproducibility of the chromatographic system. To ascertain its effectiveness, certain system suitability test parameters were checked by repetitively injecting the drug solution at the concentration level of $100 \mu \mathrm{g} / \mathrm{ml}$ and the results are shown in Table 2. For robustness evaluation of HPLC method a few parameters like flow rate, percentage of organic phase in the mobile phase and $\mathrm{pH}$ of aqueous phase (buffer) were deliberately changed. One factor was changed at one time to estimate the effect. The flow rate of the mobile phase was changed from 1.0 to 0.9 and $1.1 \mathrm{ml} / \mathrm{min}$. The organic strength of mobile phase was varied by $\pm 10 \%$ while $\mathrm{pH}$ of buffer was varied by \pm 0.2 
Volume 1, Issue 1, Serial 2: August 2012

units. Robustness of the method was done at the concentration level 100 $\mu \mathrm{g} / \mathrm{ml}$ for Vildagliptin and the results are shown in Table 3.

\section{RESULTS AND CONCLUSION}

The proposed method was optimized which gave sharp peak with minimum tailing factor for Vildagliptin (Figure 2). The retention time for Vildagliptin was 6.3 min. UV overlain spectra of Vildagliptin showed that it absorbed appreciably at $210 \mathrm{~nm}$, so this wavelength was selected as the detection wavelength. The calibration curve for Vildagliptin was found to be linear over the range of $5-200 \mu \mathrm{g} / \mathrm{ml}$. The data of regression analysis of the calibration curves is shown in Table 1. The proposed method was successfully applied to the determination of Vildagliptin in tablet dosage form. The developed method was also found to be specific, since it was able to separate other excipients present in sample solution (Figure 2). The LOD for Vildagliptin was found to be $1.47 \mu \mathrm{g} / \mathrm{ml}$, while LOQ $4.90 \mu \mathrm{g} / \mathrm{ml}$. The results for validation and system suitability test parameters are summarized in Table 2.
Results for robustness evaluation for Vildagliptin are presented in Table 3.

The proposed RP- HPLC method has the advantages of simplicity, precision, accuracy and convenience for the separation and quantization of VDG in tablet dosage form. The method was validated showing satisfactory data for all the method validation parameters tested. The developed methods can be conveniently used by quality control laboratories.

\section{ACKNOWLEDGEMENTS}

The authors thank Prof. Dr. Samir Kumar Sadhu, Head of the Department, Pharmacy Discipline, Life Science School, Khulna University, Khulna-9208, Bangladesh, for providing required facilities to carry out this project work.

\section{REFERENCES}

1. Vildagliptin, Wikipedia, http://en.wikipedia.org/wiki/Vildagliptin, (15 July 2012)

2. Ramzia I. El-Bagary, Ehab F. Elkady, Bassam M. Ayoub. Liquid Chromatographic Methods for the Determination of Vildagliptin in the 
Volume 1, Issue 1, Serial 2: August 2012

Presence of its Synthetic Intermediate and the Simultaneous Determination of Pioglitazone Hydrochloride and Metformin Hydrochloride, International Journal of Biomedical Science 7(3), 201-208, (2011)

3. Amanda Thomas Barden, Bárbara Salamon, Elfrides Eva Sherman Schapoval, and Martin Steppe; Stability-Indicating RP-LC Method for the Determination of Vildagliptin and
Mass Spectrometry Detection for a Main Degradation Product, $\mathrm{J}$ Chromatogr Sci 50(5): 426-432, (2012).

4. International Conference of Harmonisation (ICH) of Technical Requirement for the registration of Pharmaceuticals for human use. Validation of Analytical Procedures Methodology, ICH-Q 213, Geneva (1996)

5. USP 30 (2007) CD-ROM

\section{FIGURE AND TABLE}

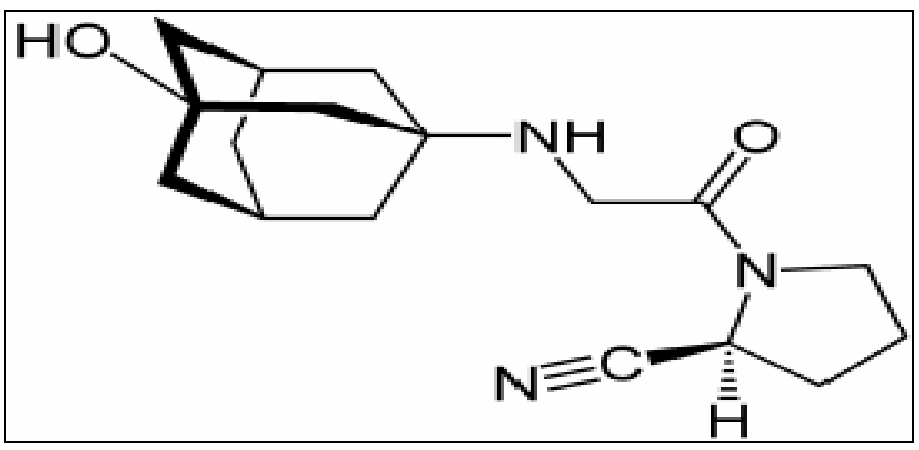

Figure 1 : Chemical Structures of Vildagliptin 
Volume 1, Issue 1, Serial 2: August 2012

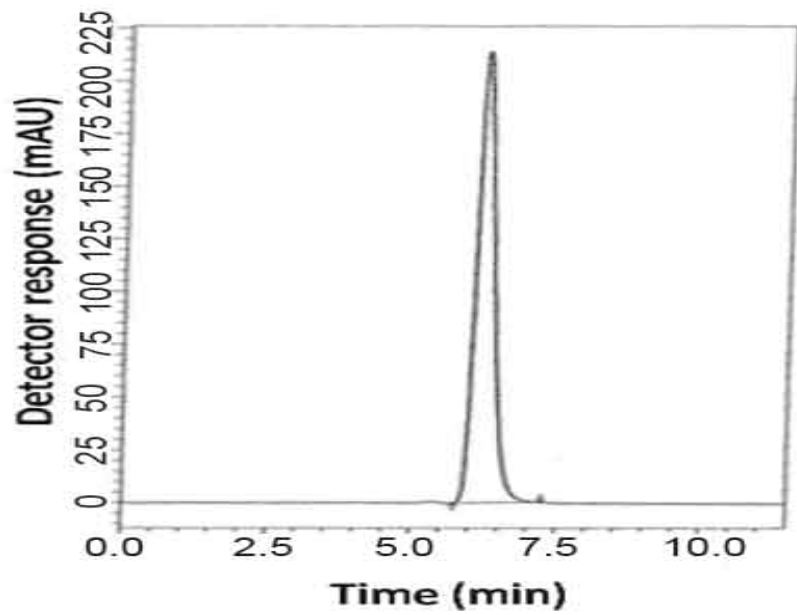

Figure 2: A typical LC chromatogram of $25 \mu \mathrm{L}$ injector of $100 \mu \mathrm{g} / \mathrm{ml}$ standard solution

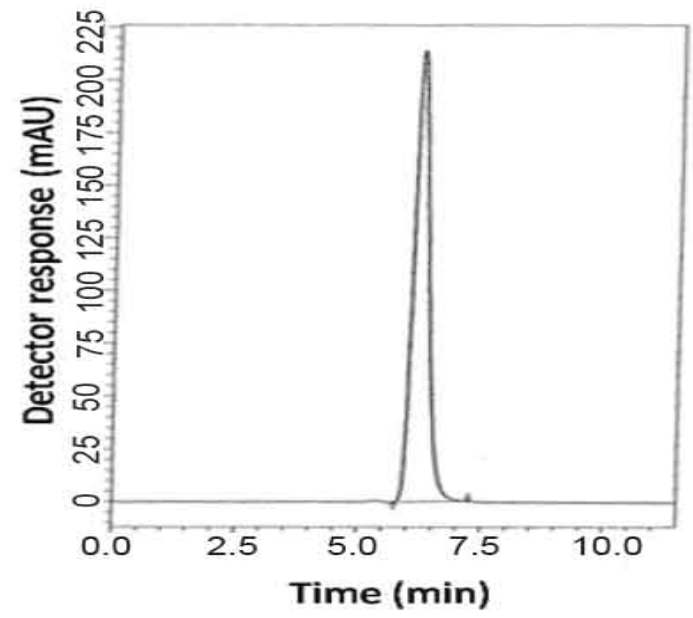

Figure 3: A typical LC chromatogram of $25 \mu \mathrm{L}$ injector of $100 \mu \mathrm{g} / \mathrm{ml}$ Galvus sample solution

Table 1: Linear Regression Data for Calibration Curves.

\begin{tabular}{ll}
\hline Parameter (Units) & Vildagliptin \\
\hline Linearity range $(\mu \mathrm{g} / \mathrm{ml})$ & $5-200$ \\
$\mathrm{R}^{2} \pm \mathrm{SD}$ & $0.9997 \pm 0.00032$ \\
Slope $\pm \mathrm{SD}$ & $0.35234 \pm 0.0101$ \\
Intercept $\pm \mathrm{SD}$ & $0.788532 \pm 0.07712$ \\
Avg. of SE of estimation & 1.182054 \\
\hline
\end{tabular}


Volume 1, Issue 1, Serial 2: August 2012

Table 2: Summary of Validation and System Suitability Test Parameters.

\begin{tabular}{lc}
\hline Parameter (Units) & Vildagliptin \\
\hline Linearity range $(\mu \mathrm{g} / \mathrm{ml})$ & $2-200$ \\
Correlation coefficient & $0.9994 \pm 0.00038$ \\
LOD $(\mu \mathrm{g} / \mathrm{ml})$ & 1.47 \\
LOQ $(\mu \mathrm{g} / \mathrm{ml})$ & 4.90 \\
Recovery $(\%)$ & $99.94 \%$ \\
& \\
Precision $(\% \mathrm{RSD})$ & \\
Interday $(\mathrm{n}=3)$ & 1.3 \\
Intraday $(\mathrm{n}=3)$ & 1.2 \\
Robustness & Robust \\
Retention Time \pm allowable time (min.) & $6.2 \pm 0.2$ \\
Theoretical Plates & 6250 \\
Tailing Factor (asymmetry factor) & 1.12 \\
\hline
\end{tabular}

Table 3: Summary of Robustness Studies for Vildagliptin

\begin{tabular}{lcccc}
\hline Factor & Level & $\begin{array}{c}\% \text { mean } \\
\text { assay }\end{array}$ & \% RSD & Retention Time (min) \\
\hline $\begin{array}{l}\text { pH of aqueous } \\
\text { phase (buffer) }\end{array}$ & 9.3 & 99.7 & 0.39 & 6.189 \\
& 9.7 & 100.1 & 1.28 & 6.288 \\
Flow rate & 0.9 & 99.6 & 1.03 & 5.589 \\
(ml/min) & 1.1 & 99.8 & 0.65 & 6.821 \\
& & & & \\
\% of organic & 36 & 99.3 & 0.95 & 7.524 \\
phase in the & 44 & 100.1 & 1.04 & 5.245 \\
mobile phase & & & & \\
\hline
\end{tabular}

